\title{
Polybrominated diphenyl ethers with broad spectrum antibacterial activity from the Indonesian marine sponge Lamellodysidea herbacea
}

\author{
Novriyandi Hanif ${ }^{*}$, Muhammad Syarqul Ardan ${ }^{1}$, Dudi Tohir ${ }^{1}$, Andi Setiawan², Nicole J. de Voogd ${ }^{3,4}$, Muhammad Farid ${ }^{1}$, \\ Anggia Murni ${ }^{5}$, Junichi Tanaka ${ }^{6}$ \\ ${ }^{1}$ Department of Chemistry, Faculty of Mathematics and Natural Sciences, Bogor Agricultural University, Bogor 16680, Indonesia. \\ ${ }^{2}$ Department of Chemistry, Faculty of Mathematics and Natural Sciences, Lampung University, Bandar Lampung 35145, Indonesia. \\ ${ }^{3}$ Naturalis Biodiversity Center, 2300 RA, Leiden, The Netherlands. \\ ${ }^{4}$ Institute of Environmental Sciences, CML. Leiden Unviersity, Leiden, The Netherlands. \\ ${ }^{5}$ Tropical Biopharmaca Research Center, Bogor Agricultural University, Bogor 16128, Indonesia. \\ ${ }^{6}$ Department of Chemistry, Biology and Marine Science, Faculty of Sciences, University of the Ryukyus, 903-0213, Okinawa, Japan.
}

\section{ARTICLE INFO \\ Received on: 14/01/2019 \\ Accepted on: 25/10/2019 \\ Available online: 03/12/2019}

\section{Key words:}

PBDE, Lamellodysidea

herbacea, NMR, X-ray

crystallography, antibiotic

resistance.

\begin{abstract}
The marine sponge Lamellodysidea herbacea is one of the marine organisms containing unique organobromine molecules polybrominated diphenyl ethers (PBDEs) which have diverse biological activities. Compounds 1-4 have been successfully isolated and their structures were elucidated using nuclear magnetic resonance (NMR) spectroscopy, single-crystal x-ray diffraction, and comparison with data in literature. Compound $\mathbf{1}, \mathrm{C}_{12} \mathrm{H}_{6} \mathrm{O}_{4} \mathrm{Br}_{6}$, was isolated in gram quantity (1.35 g) and elucidated as 2,3,4,5-tetrabromo-6-(3',5'-dibromo-2'-hydroxyphenoxy)phenol after NMR and X-ray analysis. Compound 1 takes a twist-like conformation with torsion angle $\phi_{1}=27.7(6)^{\circ} ; \phi_{2}=$ $86.5(5)^{\circ}$, while the angle of the ether bond is $117.5^{\circ}$. Compounds $2-\mathbf{4}$ were elucidated as $2,3,5$-tribromo-6-( $3^{\prime}, 5^{\prime}-$ dibromo-2'-hydroxyphenoxy)anisole, 2,3,5-tribromo-6-(3',5'-dibromomethoxyphenoxy) phenol, 2,3,5-tribromo-6(3',5'-hydroxyphenoxy)phenol, respectively. Antibacterial evaluation of 1-4 on Gram-positive and Gram-negative pathogens showed that the potent activity was at $0.08 \mu \mathrm{g} / \mathrm{disk}, 12 \pm 0 \mathrm{~mm}$ (Staphylococcus aureus ATCC 6538); 6.25 $\mu \mathrm{g} / \mathrm{disk}, 10 \pm 0 \mathrm{~mm}$ (Klebsiella pneumoniae); and $50 \mu \mathrm{g} / \mathrm{disk}, 12 \pm 0 \mathrm{~mm}$ (ampicillin-resistant Escherichia coli). Compounds 1, 2, and 4 showed ichthyotoxicity (zebrafish embryos, Danio rerio) at a level of $\mathrm{LC}_{50}>10 \mu \mathrm{g} / \mathrm{ml}$ [dead, 48 hours postfertilization (hpf)]. This is the first report that compound 4 inhibits the growth of antibiotic-resistant bacteria.
\end{abstract}

\section{INTRODUCTION}

Infectious disease is defined as any cause by pathogenic microorganisms, such as bacteria, viruses, parasites, or fungi, which can be directly or indirectly spread from one person to another. This problem becomes even more difficult if antimicrobial resistance is faced. Of the 194 countries, only 129 countries provided any national data on drug resistance (Reardon 2014). Most countries had found to have five antibiotic-resistant bacteria-drug pairs

\section{"Corresponding Author}

Novriyandi Hanif, Department of Chemistry, Faculty of Mathematics and Natural Sciences, IPB University (Bogor Agricultural University),

Bogor 16680,Indonesia.E-mail: nhanif@apps.ipb.ac.id
(Reardon 2014). The challenge is even greater in developing countries where the burden of infectious disease is high. This is because of the increasing use of antibiotics, poor sanitation and hygiene in communities and hospitals, and the increasing frequency of global travel, trade, and disease transmission (Laxminarayan et al. 2013). Indonesia has started to face this problem since 1990 (Parathon et al. 2017). Survey of Indonesian public hospitals reported that patients in the national hospital were increased for antibiotic-resistant Escherichia coli (52\%), Enterobacteriaceae producing extended-spectrum $\beta$-lactamase, Klebsiella pneumoniae (58\%), and methicillin-resistant Staphylococcus aureus (MRSA) (Hadi et al. 2013). This was due to the high inappropriate use of antibiotics. In the global issue, infectious diseases caused by pathogenic Gram-positive vancomycin-resistant enterococci (VRE) and MRSA have paid attention over the past two decades. 
However, the global current focus is emphasized to discover new antibiotics that can cure infectious diseases from Gram-negative Enterococcus faecium, S. aureus, K. pneumoniae, Acinetobacter baumanii, Pseudomonas aeruginosa, and Enterobacter species pathogens and their resistant forms. This pressing treatment challenge is that because the discovery for Gram-negative antibiotics is more difficult than those of Gram-positive bacteria (Walsh and Wencewicz, 2014). Only two approvals of antibiotic drugs, synercid and daptomycin, are largely used in response to VRE and MRSA, and there had not been a new antibiotic scaffold for Gram-negative pathogens (Walsh and Wencewicz, 2014). In 2015, a polybrominated diphenyl ether (PBDE) discovered from the marine sponge Dysidea (Lamellodysidea) was able to inhibit various pathogenic Gram-negative bacteria including resistant strains (Sun et al., 2015).

The marine sponge Lamellodysidea herbacea is known to have a unique group of marine natural products named with PBDEs. Interestingly, the true producer of PBDE was revealed as a marine cyanobacterium Oscillatoria spongelliae (Faulkner et al., 1994). This class of compounds has been found to exhibit a variety of bioactivities such as antibacterial (Handayani et al. 1997; Hanif et al., 2007; Liu et al., 2016; Sun et al., 2015), antifungal (Sionov et al., 2005), anti-cancer (Arai et al., 2017; Fu et al., 1995; Liu et al., 2004; Xu et al. 2005), and antiviral (Salam et al., 2014; Yamashita et al., 2015). PBDE is a unique molecule containing phenyl rings, $-\mathrm{OH}$, ether, and $-\mathrm{Br}$ functional groups. The latter group is very useful in aromatic chemistry as a protecting group (Choi and Chi, 2001; Effenberger, 2002) and is rarely explored. All isolated PBDEs were evaluated for their activities using Gram-positive $S$. aureus and Gram-negative bacteria, including $K$. pneumoniae and E. coli ampicillin resistance. To become ready as antibacterial drug leads, we combine our assays using zebrafish embryos toxicity assay (Hanif et al., 2018). Antibacterial drugs should have the lowest possible toxic effect. It is quite challenging to discover antibacterial drugs with the lowest toxicity effect (Walsh and Wencewicz, 2014).

In our continuing interest on bioactive marine organisms (Hanif et al., 2018), four compounds (1-4) have been successfully isolated from the marine sponge $L$. herbacea collected in Ujung Kulon, and their structures were elucidated using NMR and IR spectroscopy, X-ray crystallography, and electrospray ionization mass spectrometry (ESIMS) spectrometry as well as comparison with the data in literature. We also evaluated the isolated compounds against Gram-positive $S$. aureus, Gram-negative K. pneumoniae, and $E$. coli ampicillin-resistant pathogens. Embryos zebrafish Danio rerio were used to evaluate the isolated compounds for their toxicity. We report here the isolation and structure elucidation of the compounds and the results of bioactivities.

\section{MATERIAL AND METHODS}

\section{General}

Ultraviolet (UV) and IR spectra were obtained on a Perkin Elmer Spectrum One Fourier-transformed infrared and on a Shimadzu pharmaspec 1700 spectrophotometer, respectively. ESIMS data were obtained from Waters Acquity Xevo G2-S quadrupole time-of-flight mass spectrometry with positive mode, and nuclear magnetic resonance (NMR) spectra were recorded on a Bruker Avance III 500 spectrometer $\left(500 \mathrm{MHz}\right.$ for $\left.{ }^{1} \mathrm{H}\right)$. Chemical shifts $(\delta)$ were referenced to trimethylsilane, deuterated chloroform $\left(\mathrm{CDCl}_{3}\right)$, or deuterated acetone $\left(\mathrm{Me}_{2} \mathrm{CO}-d_{6}\right)$ signals and are expressed in parts per million (ppm), and coupling constants $(J)$ are in Hz. X-ray analysis was performed on a Rigaku AFC10 goniometer equipped with a Saturn 724+ detector. Highperformance liquid chromatography (HPLC) separations were carried out on a Hitachi L-6000 pump fitted with a Shodex RI101 refractive index and SPD-20A Shimadzu UV detectors. The column used for HPLC was Cosmosil 5SL-II-MS $(10 \times 250 \mathrm{~mm})$, and analytical thin-layer chromatography (TLC) was performed on Merck silica gel 60 F254 plates and visualized with sulfuric acid with cerium sulfate. All solvents used were reagent grade.

\section{Animal material}

The marine sponge was collected by hand using scuba off Ujung Kulon, Indonesia, in March 2018. A voucher specimen has been deposited in the Department of Chemistry, IPB University, Indonesia (Code NH-G1-0067-17c).

\section{Extraction and isolation}

The marine sponge specimen (wet, $300 \mathrm{~g}$ ) stored in ethanol $\left(\mathrm{EtOH}, \mathrm{C}_{2} \mathrm{H}_{6} \mathrm{O}\right)$ was extracted three times using methanol $\left(\mathrm{MeOH}, \mathrm{CH}_{4} \mathrm{O}\right)(3 \times 200 \mathrm{ml})$. The combined extracts were concentrated under reduced pressure, and the residue was partitioned between $n$-hexane $\left(\mathrm{C}_{6} \mathrm{H}_{14}\right)$ and aqueous methanol $\left(\mathrm{MeOH}, \mathrm{CH}_{4} \mathrm{O}\right)(90 \%)$. The latter layer was partitioned further between dichloromethane $\left(\mathrm{CH}_{2} \mathrm{Cl}_{2}\right)$ and aqueous methanol $\left(\mathrm{MeOH}, \mathrm{CH}_{4} \mathrm{O}\right)(50 \%)$. After the removal of methanol $(\mathrm{MeOH}$, $\mathrm{CH}_{4} \mathrm{O}$ ) from the latter layer and the addition of water $\left(\mathrm{H}_{2} \mathrm{O}\right)$, the residue was extracted with $n$-butanol $\left(n-\mathrm{BuOH}, \mathrm{C}_{4} \mathrm{H}_{10} \mathrm{O}\right)$. All layers (n-hexane, $\mathrm{C} 6 \mathrm{H} 14$; dichloromethane, $\mathrm{CH} 2 \mathrm{Cl} 2$; n-butanol, n-BuOH, C4H10O) were checked for their activity against Grampositive and Gram-negative bacteria. Crystallization of the most active layer $\left(\mathrm{CH}_{2} \mathrm{Cl}_{2}\right)$ from $\mathrm{CHCl}_{3}-\mathrm{Me}_{2} \mathrm{CO}-\mathrm{MeCN}$ (1:1:2) gives 1 (1.36 $\mathrm{g}$ in total). A noncrystalline fraction was successively separated using either a silica gel column eluted with hexaneEtOAc, EtOAc- $\mathrm{MeOH}$, and $\mathrm{MeOH}$ followed by recrystallization, or by silica HPLC eluted with hexane-EtOAc to give compound $\mathbf{2}$ (5.4 mg), a mixture of compounds $\mathbf{2}$ and $\mathbf{3}(5.6 \mathrm{mg})$, and compound 4 (136.5 mg).

\section{Evaluation of antibacterial activity and toxicity against fish embryos}

Antibacterial activity (Hanif et al., 2007) was evaluated using agar-plate diffusion assay. Paper disks were impregnated with isolated compounds ranging from 0.08 to $50 \mu \mathrm{g} /$ disks and placed on agar plates inoculated with $S$. aureus ATCC 6538, $K$. pneumoniae, E. coli, or ampicillin-resistant $P$. aeruginosa was used qualitatively to check whether the layer was active or not. Prior to and after the testing, all the materials were sterilized at $121^{\circ} \mathrm{C}$ for 20 mintues. DMSO was used as a negative control, while ampicillin and chlorampenicol were used as a positive control.

For toxicity (Hanif et al., 2018), fertilized and normally developed embryos of $D$. rerio were used. A series of sample concentrations was prepared from 1.25 to $10 \mu \mathrm{g} / \mathrm{mL}$. After the 4-hour fertilization, the eggs were collected and rinsed with an 
embryo rearing solution medium. The fertilized and normally divided eggs were selected under the microscope. The embryos were exposed to the compounds for 24,48 , and 72 hours in $24-$ well microplates. Observation of the embryos was based on whether it is dead or alive. The number of embryos used for each assay was 10. A positive control was 3,4-dichloroaniline, while the negative control was DMSO. The $\mathrm{LC}_{50}$ was calculated by using the statistical software SPSS IBM 23.0. The experiment was repeated three times.

\section{NMR analysis}

A sample dissolved in $\mathrm{CDCl}_{3}$ or $\mathrm{Me}_{2} \mathrm{CO}-d_{6}$ or a mixture of the two NMR solvents was measured with a Bruker Avance III 500 spectrometer $\left(500 \mathrm{MHz}\right.$ for $\left.{ }^{1} \mathrm{H}\right)$. The samples were measured for their ${ }^{1} \mathrm{H}$ NMR after scanning for 16-32 times. Tetramethylsilane was used as an internal standard.

\section{X-ray analysis}

All measurements were made on a Rigaku AFC10 goniometer equipped with Saturn724+ detector mounted graphite monochromated Mo-K $\alpha$ radiation $(\lambda=0.71075 \AA)$. A suitable crystal was selected and mounted in inert oil and transferred to the cold $\mathrm{N}_{2}$ gas stream of the diffractometer. The crystal was kept at $123 \mathrm{~K}$ during data collection. The data were collected using CrystalClear-SM 1.4.0 SP1 (Rigaku, 2008) and processed with CrysAlisPro 1.171.39.46 (Rigaku, 2018).

Using Olex2 (Dolomanov et al., 2009), the structure was solved by the SHELXT (Sheldrick, 2015) structure solution program using Direct Methods and expanded using Fourier techniques. The non-hydrogen atoms were refined anisotropically. Hydrogen atoms were refined using the riding model. The structure was refined with the SHELXL (Sheldrick, 2008) refinement package using least-squares minimization. All hydrogen atoms were placed in idealized positions and refined as riding atoms isotropically. The crystal data, data collection, and structure refinement can be seen in Table 1 .

\section{RESULT AND DISCUSSION}

Four PBDEs 1-4 have been isolated and their structures were identified by analyzing NMR, IR, UV spectral data, and $\mathrm{X}$-ray diffraction study as well as comparison with published data in literatures. The major compound $\mathbf{1}, \mathrm{C}_{12} \mathrm{H}_{4} \mathrm{O}_{3} \mathrm{Br}_{6}$, was obtained as crystals. The molecular formula of $\mathbf{1}$ was also confirmed by ESIMS $[\mathrm{M}+\mathrm{Na}]^{+}$to have $\mathrm{C}_{12} \mathrm{H}_{4} \mathrm{O}_{3} \mathrm{Br}_{6} \mathrm{Na}$.

The ${ }^{1} \mathrm{H}$ NMR spectrum taken in $\mathrm{CDCl}_{3}$ exhibited only a pair of meta-coupled signals at $\delta 6.36(1 \mathrm{H}, d, J=2.2 \mathrm{~Hz})$ and $7.41(1 \mathrm{H}, d, J=2.2 \mathrm{~Hz})$. The presence of phenolic hydroxyls was inferred by the IR spectrum $\left(3490 \mathrm{~cm}^{-1}\right)$. The presence of a substituted phenol group with auxochromes was also confirmed by UV absorption at $\lambda_{\text {max }}(\log \varepsilon) 293.4 \mathrm{~nm}$ (2.98). Comparison of the NMR data with those in literature (Calcul et al., 2009; Hanif et al., 2007; Norton et al., 1981) concluded that compound $\mathbf{1}$ is a hexabrominated diphenyl ether. Since the ratio of $\mathrm{H} / \mathrm{C}$ is less than 1 , confirmation of the chemical structure of $\mathbf{1}$ is very suitable for $\mathrm{X}$-ray crystallography. X-ray analysis disclosed the conformation of $\mathbf{1}$ in addition to the structure as in Figure 1. Compound $\mathbf{1}$ takes a twist-like conformation with $\phi_{1}=27.7(6)^{\circ} ; \phi_{2}=86.5(5)^{\circ}$ and the angle of ether bond is $117.5^{\circ}$. This conformation may be explained by the presence of an ortho-bromo substituent (Klösener et al., 2008; Luthe et al., 2008) and by the rotation barrier of the metaand the para-substitutions as well as a buttressing effect (Luthe et al., 2008).

The ${ }^{1} \mathrm{H}$ NMR data of 2 taken in $\mathrm{CDCl}_{3} / \mathrm{Me}_{2} \mathrm{CO}-d_{6}(2 / 1)$ showed the presence of meta-coupled protons at $\delta 6.53(1 \mathrm{H}, \mathrm{d}, J=$ $1.5 \mathrm{~Hz})$ and $7.36(1 \mathrm{H}, \mathrm{d}, J=1.5 \mathrm{~Hz})$ as in 1 with a methoxy group $(\delta$ $3 \mathrm{H}, \mathrm{s}, 3.84)$ in one of the rings. An additional aromatic singlet at $\delta$ $7.78(1 \mathrm{H}, \mathrm{s})$ suggested that $\mathbf{2}$ is a debromo analog of $\mathbf{1}$. Comparison with literature values (Norton et al., 1981) confirmed that $\mathbf{2}$ is 3,5-tribromo-6-(3',5'-dibromo-2'-hydroxyphenoxy)anisole. Crystals of compound 2 were formed using the $\mathrm{CHCl}_{3}-\mathrm{Me}_{2} \mathrm{CO}$ solution at room temperature. The purity of compound $\mathbf{2}$ was confirmed using TLC analysis to give $R_{f} 0.62$ [Hex/EtOAc, 4/1].

Compound 3 was elucidated as 2,3,5-tribromo-6-(3',5'dibromomethoxyphenoxy)phenol after analyzing NMR spectra taken in $\mathrm{CDCl}_{3} / \mathrm{Me}_{2} \mathrm{CO}-d_{6}(1 / 1)$ and comparing the data with literature (Hanif et al., 2007; Norton et al., 1981). Two methoxy groups were observed at $\delta 3.84(3 \mathrm{H}, s)$ and $3.85(3 \mathrm{H}, s)$. The remaining signals agreed for two sets of meta-coupled protons at $\delta 6.62(1 \mathrm{H}, d, J=2.1 \mathrm{~Hz})$ and $7.37(1 \mathrm{H}, d, J=2.1 \mathrm{~Hz})$. Two

Table 1. Crystal data, data collection, and structure refinement.

\begin{tabular}{|c|c|}
\hline Crystal data & \\
\hline Chemical formula & $\mathrm{C}_{12} \mathrm{H}_{4} \mathrm{Br}_{6} \mathrm{O}_{3} \cdot \mathrm{H}_{2} \mathrm{O}$ \\
\hline$M_{\mathrm{r}}$ & 693.63 \\
\hline Crystal system, space group & Monoclinic, $P 2_{1} / n$ \\
\hline Temperature (K) & 123 \\
\hline$a, b, c(\AA)$ & $4.74979(10), 18.7360(3), 18.3463(4)$ \\
\hline$\beta\left({ }^{\circ}\right)$ & $91.6135(19)$ \\
\hline$V\left(\AA^{3}\right)$ & $1632.02(6)$ \\
\hline$Z$ & 4 \\
\hline Radiation type & Mo $K \alpha$ \\
\hline$\mu\left(\mathrm{mm}^{-1}\right)$ & 14.77 \\
\hline Crystal size (mm) & $0.28 \times 0.28 \times 0.22$ \\
\hline \multicolumn{2}{|l|}{ Data collection } \\
\hline Diffractometer & $\begin{array}{l}\text { Rigaku AFC10 goniometer with Saturn } \\
724+\text { detector }\end{array}$ \\
\hline Absorption correction & $\begin{array}{l}\text { Numerical CrysAlis PRO 1.171.39.46 (Rigaku } \\
\text { Oxford Diffraction, 2018) Spherical absorption } \\
\text { correction using equivalent radius and absorption } \\
\text { coefficient. Empirical absorption correction using } \\
\text { spherical harmonics, implemented in SCALE3 } \\
\text { ABSPACK scaling algorithm. }\end{array}$ \\
\hline$T_{\min }, T_{\max }$ & $0.006,0.024$ \\
\hline $\begin{array}{l}\text { No. of measured, independent and } \\
\text { observed }[I>2 \sigma>I)] \text { reflections }\end{array}$ & $20,780,4,898,4,152$ \\
\hline$R_{\text {int }}$ & 0.037 \\
\hline$(\sin \theta / \lambda)_{\max }\left(\AA^{-1}\right)$ & 0.728 \\
\hline \multicolumn{2}{|l|}{ Refinement } \\
\hline$\left.R\left[F^{2}>2 \sigma>F^{2}\right)\right], w R\left(F^{2}\right), S$ & $0.044,0.127,1.09$ \\
\hline No. of reflections & 4898 \\
\hline No. of parameters & 207 \\
\hline No. of restraints & 3 \\
\hline $\mathrm{H}$-atom treatment & $\mathrm{H}$-atom parameters constrained \\
\hline$\left.\Delta\rangle_{\max }, \Delta\right\rangle_{\min }\left(\mathrm{e} \AA^{-3}\right)$ & $1.42,-0.77$ \\
\hline
\end{tabular}


singlet aromatic signals appeared in $7.83(1 \mathrm{H}, s)$ and $7.80(1 \mathrm{H}, s)$. The former downfield signal was dealt with the presence of the methoxy group in A ring (Hanif et al., 2007; Norton et al., 1981). In addition, the TLC analysis of the NMR sample indicated two spots with $R_{f} 0.62\left[\mathrm{Hex} / \mathrm{EtOAc} 4 / 1, \mathrm{Ce}\left(\mathrm{SO}_{4}\right)_{2}\right]$ and $R_{f} 0.52[\mathrm{Hex} /$ EtOAc 4/1]. This result clearly indicates that compounds 2 and 3 were in a mixture with ratio 1:1 (1: 0.94 in NMR integration).

Compound 4 was shown to have molecular formula $\mathrm{C}_{12} \mathrm{H}_{5} \mathrm{Br}_{5} \mathrm{O}_{3}$ after NMR analysis $\left(\mathrm{Me}_{2} \mathrm{CO}-d_{6}\right)$ and comparing the data with literature values (Norton et al., 1981). A pair of metacoupled protons at $\delta 6.83(1 \mathrm{H}, d, J=2.2 \mathrm{~Hz})$ and $7.39(1 \mathrm{H}, d, J=$ $2.2 \mathrm{~Hz})$ and an aromatic singlet at $\delta 7.56(1 \mathrm{H}, s)$ were observed.
The absence of a methoxy group in $\mathbf{4}$ suggested that $\mathbf{4}$ is a demethoxy analog of $\mathbf{2}$. The purity of $\mathbf{4}$ was confirmed by using HPLC and NMR analysis. Compound 4 is 2,3,5-tribromo-6-( $3^{\prime}, 5^{\prime}-$ dibromophenoxy)phenol. Chemical structures of compounds 2-4 are shown in Figure 2.

The results of the antibacterial assays are shown in Table 2. In the standard disk diffusion assay, compounds $\mathbf{1}$ and 4 showed activity against $S$. aureus ATCC 6538 in the range of $0.08-1.25 \mu \mathrm{g} /$ disk with zone of inhibition $16 \pm 0-14 \pm 0$ mm, while compounds $\mathbf{1}$ and $\mathbf{4}$ exhibited activity against $K$. pneumoniae in the range of $6.25-50 \mu \mathrm{g}$ /disk with inhibition zone as $13 \pm 0-10 \pm 0 \mathrm{~mm}$. Only compound 4 inhibited the<smiles>Oc1c(Br)cc(Br)cc1Oc1c(O)c(Br)c(Br)c(Br)c1Br</smiles>

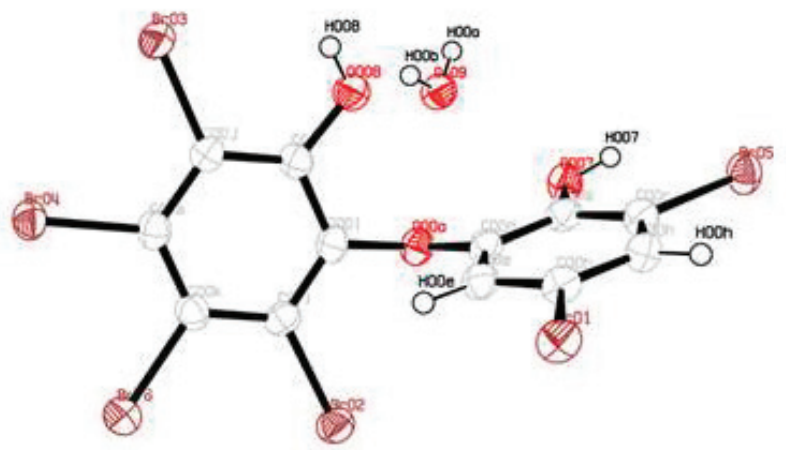

Figure 1. Chemical structure of $\mathbf{1}$ and crystal structure of $\mathbf{1}$ with displacement ellipsoids drawn at the $50 \%$ probability level.<smiles>COc1c(Br)cc(Br)cc1Oc1c(Br)cc(Br)c(Br)c1Oc1c(Br)cc(Br)cc1Oc1c(Br)cc(Br)c(Br)c1Oc1cc(Br)cc(Br)c1O</smiles>

Figure 2. Chemical structure of 2-4.

Table 2. Antibacterial activity against S. aureus ATCC 6538 and K. pneumonia.

\begin{tabular}{cccccccccccc}
\hline & \multicolumn{8}{c}{ Concentration $(\boldsymbol{\mu g} /$ disk)/Zone inhibition \pm Standard deviation $(\mathbf{m m})$} \\
\cline { 2 - 12 } Com. & \multicolumn{9}{c}{ S. aureus ATCC $\mathbf{6 5 3 8}$} \\
\cline { 2 - 13 } & $\mathbf{0 . 0 8}$ & $\mathbf{0 . 1 6}$ & $\mathbf{0 . 3 1}$ & $\mathbf{0 . 6 3}$ & $\mathbf{1 . 2 5}$ & $\mathbf{1 . 5 6}$ & $\mathbf{3 . 1 3}$ & $\mathbf{6 . 2 5}$ & $\mathbf{1 2 . 5}$ & $\mathbf{2 5}$ & $\mathbf{5 0}$ \\
\hline 1 & $12 \pm 0$ & $12.5 \pm 0.71$ & $12.5 \pm 0.71$ & $13 \pm 0$ & $14 \pm 0$ & $0 \pm 0$ & $0 \pm 0$ & $0 \pm 0$ & $9 \pm 0$ & $10 \pm 0$ & $12.5 \pm 0.71$ \\
2 & $0 \pm 0$ & $0 \pm 0$ & $0 \pm 0$ & $9 \pm 0$ & $9 \pm 0$ & $0 \pm 0$ & $0 \pm 0$ & $9 \pm 0$ & $0 \pm 0$ & NT & NT \\
4 & $12 \pm 0$ & $13 \pm 0$ & $14 \pm 0$ & $15 \pm 0$ & $16 \pm 0$ & $0 \pm 0$ & $0 \pm 0$ & $10 \pm 0$ & $10 \pm 0$ & $11 \pm 0.71$ & $13 \pm 0$ \\
\hline
\end{tabular}

$\mathrm{NT}=$ not tested. 
growth of ampicillin-resistant $E$. coli at $12 \pm 0 \mathrm{~mm}$ at $50 \mu \mathrm{g} /$ disk. These results point out that the presence of two phenolic hydroxyl groups as well as the less number of bromine atoms is important for the antibacterial activity. The finding also showed the antibacterial drug leads not only active against Grampositive bacteria, but also especially against Gram-negative ampicillin-resistant $E$. coli. In the toxicity assay against embryos of the zebrafish $D$. rerio, compounds $\mathbf{1}, \mathbf{2}$, and $\mathbf{4}$ did not kill the embryos at $10 \mu \mathrm{g} / \mathrm{ml}$.

\section{CONCLUSION}

Compounds 1-4 belonging to PBDEs were isolated and their structures were identified by using NMR spectroscopy, single-crystal X-ray diffraction, and comparison with the data in literature. Compound $\mathbf{1}$ has a twist-like conformation with torsion angle $\phi_{1}=27.7(6)^{\circ} ; \phi_{2}=86.5(5)^{\circ}$, while the angle of the ether bond is $117.5^{\circ}$. The isolated PBDEs showed broad-spectrum antibacterial, activity, especially Gram-negative bacteria $K$. pneumoniae and ampicillin-resistant $E$. coli. This is the first report in which compound $\mathbf{4}$ showed antibacterial activity.

\section{ACKNOWLEDGMENTS}

This work was supported by the National Research Foundation, Indonesian Ministry of Research, Technology, and Higher Education, Indonesia, under its excellence basic research university program (1769/IT3.11/PN/2018) awarded to N.H.

\section{AUTHORS' CONTRIBUTION}

Conceived and designed the experiments: N.H. and J.T. Performed the experiments: N.H., M.S.A., D.T., A.M., and J.T. Analyzed the data: M.S.A., D.T., M.F.D., NJdV, A.M., J.T.. Contributed reagents/materials/analysis tools: N.H. and J.T. Wrote the paper: N.H. and J.T.

\section{CONFLICT OF INTEREST}

The authors have declared that no competing interests exist.

\section{FINANCIAL SUPPORT}

This research was funded by Indonesian Ministry of Research, Technology, and Higher Education, Indonesia awarded to N.H.

\section{REFERENCES}

Arai M, Shin D, Kamiya K, Ishida R, Setiawan A, Kotoku N, Kobayashi M. Marine spongean polybrominated diphenyl ethers, selective growth inhibitors against the cancer cells adapted to glucose starvation, inhibits mitochondrial complex II. J Nat Med, 2017; 71:44-9.

Calcul L, Chow R, Oliver AG, Tenney K, White KN, Wood AW, Fiorilla C, Crews P. NMR strategy for unravelling structures of bioactive sponge-derived oxy-polyhalogenated diphenyl ethers. J Nat Prod, 2009; 72:443-9.

Choi HY, Chi DY. A facile debromination reaction: can bromide now be used as a protective group in aromatic systems. J Am Chem Soc, 2001; 123:9202-3.

Dolomanov OV, Bourhis LJ, Gildea RJ, Howard JAK, Puschmann H. OLEX2: a complete structure solution, refinement and analysis program. J Appl Cryst, 2009; 42:339-41.

Effenberger F. How attractive is bromine as a protecting group in aromatic chemistry?. Angew Chem Int Ed Engl, 2002; 41: 1699-700.
Faulkner DJ, Unson MD, Bewley CA. The chemistry of some sponges and their symbionts. Pure Appl Chem, 1994; 66:1983-90.

Fu X, Schmitz FJ, Govindan M, Abbas SA, Hanson KM, Horton PA, Crews P, Laney M, Schatzman RC. 1995. Enzyme inhibitors: new and known polybrominated phenols and diphenyl ethers from four Indo-pacific Dysidea. sponges. J Nat Prod, 1995; 58:1384-91.

Hadi U, Kuntaman, Qiptiyah M, Paraton H. Problem of antibiotic and antimicrobial resistance in Indonesia: are we really making progress? Indones J Trop Infect Dis, 2013; 4:5-8.

Handayani D, Edrada RA, Proksch P, Wray V, Witte L, van Soest RWM, Kunzmann A, Soedarsono. Four new bioactive polybrominated diphenyl ethers of the sponge Dysidea herbacea from West Sumatra, Indonesia. J Nat Prod, 1997; 60:1313-6.

Hanif N, Tanaka J, Setiawan A, Trianto A, de Voogd NJ, Murni A, Tanaka C, Higa T. Polybrominated Diphenyl Ethers from the Indonesian Sponge Lamellodysidea herbacea. J Nat Prod, 2007; 70:432-5.

Hanif N, Ardianti R, Ahmadi P, Setiawan A, Mohamad K, de Voogd NJ, Murni A, Tanaka J. Ichthytoxic principles against zebrafish embryos from the Indonesian marine sponge Neopetrosia chaliniformis. J Appl Phar Sci, 2018; 8:44-8.

Klösener J, Swenson DC, Robertson LW, Luthe G. Electrostatic and aspheric influence of the floro-substitution of 4-bromodiphenyl ether (PBDE3). Acta Crystallogr B, 2008; 64:108-19.

Laxminarayan R, Duse A, Wattal C, Zaidi AKM, Wertheim HFL, Sumpradit N, Vlieghe E, Hara GL, Gould IM, Goosens H, Greko C, So AD, Bigdeli M, Tomson G, Woodhouse W, Ombaka E, Peralta AQ, Qamar FN, Mir F, Kariuki S, Bhutta ZA, Coates A, Bergstrom R, Wright $\mathrm{GD}$, Brown ED, Cars O. Antibiotic resistance-the need for global solutions. Lancet Infect Dis, 2013; 13:1057-98.

Liu H, Lohith K, Rosario M, Pulliam TH, O'Connor RDO, Bell LJ, Bewley CA. Polybrominated diphenyl ethers: structure determination and trends in antibacterial activity. J Nat Prod, 2016; 79:1872-6.

Liu H, Namikoshi M, Meguro S, Nagai H, Kobayashi H, Yao $\mathrm{X}$. Isolation and characterization of polybrominated diphenyl ethers as inhibitors of microtubule assembly from the marine sponge Phyllospongia. dendyi collected at Palau. J Nat Prod, 2004; 67:472-4.

Luthe G, Jacobus JA, Robertson LW. Receptor interactions by polybrominated diphenyl ethers versus polychlorinated biphenyl: a theoritical structure-activity assessment. Environ Toxicol Pharmacol, 2008, 25:202-10.

Norton RS, Croft KD, Wells RJ. Polybrominated oxydiphenol derivatives from the sponge Dysidea herbacea: Structure determination by analysis of ${ }^{13} \mathrm{C}$ spin-lattice relaxation data for quaternary carbons and $13 \mathrm{C}$ 1H coupling constants. Tetrahedron, 1981; 13:2341-9.

Reardon S. Antibiotic resistance sweeping developing world. Nature, 2014; 509:141-2.

Rigaku Japan, CrystalClear-SM 1.4.0 SP1, Tokyo, Japan, 2008. Rigaku Oxford Diffraction. US, CrysAlisPro 1.171.39.46, 2018

Salam KA, Furuta A, Noda N, Tsuneda S, Sekiguchi Y, Yamashita A, Moriishi K, Nakakoshi M, Tani H, Roy SR, Tanaka J, Tsubuki M, Akimitsu N. PBDE: structure-activity studies for the inhibition of hepatitis C virus NS3 helicase. Molecules, 2014; 19:4006-20.

Sheldrick GM. A short history of SHELX. Acta Cryst, 2008; A64:112-64.

Sheldrick GM. Crystal structure refinement with SHELX. Acta Cryst, 2015; C71:3-8.

Sun S, Canning CB, Bhargava K, Sun X, Zhu W, Zhou N, Zhang Y, Zhou K. Polybrominated dipheyl ethers with potent and broad spectrum antimicrobial activity from the marine sponge Dysidea. Bioorg Med Chem Lett, 2015; 25:2181-3.

Sionov E, Roth D, Sandovsky-Losica H, Kashman Y, Rudi A, Chill L, Berdicevsky I, Segal E. Antifungal effect and possible mode of activity of a compound from the marine sponge Dysidea herbacea. J Infect, 2005; 50:453-60

Walsh CT, Wencewicz TA. Prospect for new antibiotics: a molecule-centered perspective. J Antibiot, 2014; 67:7-22. 
Xu Y, Johnson RK, Hecht SM. Polybrominated diphenyl ethers from a sponge of the Dysidea. genus that inhibit Tie2 kinase. Bioorg Med Chem, 2005; 13:657-9.

Yamashita A, Fujimoto Y,Tamaki M, Setiawan A, Tanaka T, Okuyama-Dobashi K, Kasai H, Watashi K, Wakita T, Toyama M, Baba M, de Voogd NJ, Maekawa S, Enomoto N, Tanaka J, Moriishi K. Identification of antiviral targeting hepatitis B virus promoter from extracts of Indonesian marine organisms by a novel cell-based screening assay. Mar Drugs, 2015; 13:6759-73.
How to cite this article:

Hanif N, Ardan MS, Tohir D, Setiawan A, de Voogd NJ, Farid M, Murni A, Tanaka J. Polybrominated diphenyl ethers with broad spectrum antibacterial activity from the Indonesian marine sponge Lamellodysidea herbacea. J Appl Pharm Sci, 2019; 9(12):001-006. 